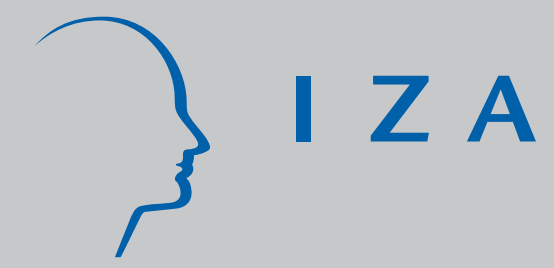

IZA DP No. 1038

Exchange Rate Volatility and Employment Growth: Empirical Evidence from the CEE Economies

Ansgar Belke

Ralph Setzer

March 2004 


\title{
Exchange Rate Volatility and Employment Growth: Empirical Evidence from the CEE Economies
}

\author{
Ansgar Belke \\ University of Hohenheim \\ and IZA Bonn
}

Ralph Setzer

University of Hohenheim

\section{Discussion Paper No. 1038 \\ March 2004}

\author{
IZA \\ P.O. Box 7240 \\ 53072 Bonn \\ Germany \\ Phone: +49-228-3894-0 \\ Fax: +49-228-3894-180 \\ Email: iza@iza.org
}

\begin{abstract}
Any opinions expressed here are those of the author(s) and not those of the institute. Research disseminated by IZA may include views on policy, but the institute itself takes no institutional policy positions.
\end{abstract}

The Institute for the Study of Labor (IZA) in Bonn is a local and virtual international research center and a place of communication between science, politics and business. IZA is an independent nonprofit company supported by Deutsche Post World Net. The center is associated with the University of Bonn and offers a stimulating research environment through its research networks, research support, and visitors and doctoral programs. IZA engages in (i) original and internationally competitive research in all fields of labor economics, (ii) development of policy concepts, and (iii) dissemination of research results and concepts to the interested public.

IZA Discussion Papers often represent preliminary work and are circulated to encourage discussion. Citation of such a paper should account for its provisional character. A revised version may be available on the IZA website (www.iza.org) or directly from the author. 
IZA Discussion Paper No. 1038

March 2004

\section{ABSTRACT \\ Exchange Rate Volatility and Employment Growth: Empirical Evidence from the CEE Economies*}

According to the traditional 'optimum currency area' approach, not much will be lost from a very hard peg to a currency union if there has been little reason for variations in the exchange rate. This paper takes a different approach and highlights the fact that high exchange rate volatility may as well signal high costs for labor markets. The impact of exchange rate volatility on labor markets in the CEECs is analyzed, finding that volatility visà-vis the euro significantly lowers employment growth. Hence, the elimination of exchange rate volatility could be considered as a substitute for a removal of employment protection legislation.

JEL Classification: F36, J32, P27

Keywords: Central and Eastern Europe, currency union, euroization, exchange rate variability, job creation

Corresponding author:

Ansgar Belke

Department of Economics

University of Hohenheim

Museumsflügel

70599 Stuttgart

Germany

Tel.: +497114593246

Fax: +497114593815

Email: belke@uni-hohenheim.de

\footnotetext{
* We thank Jarko Fidrmuc for the delivery of valuable monthly data on exchange rates, consumer price indices and annual employment data and for the calculation of an extensive number of trade weights. We also profited very much from comments by Daniel Gros, Paul de Grauwe, and Gene Liang.
} 


\section{Introduction}

The transition process from a centrally planned economy to a market economy in Central and Eastern Europe has been accompanied by a large decline in employment. While relative improvements have been recorded in some countries for the last two years, unemployment reduction has still been modest in relation to expectations. At the beginning of the transition process it was widely assumed that the sharp immediate increase in open unemployment would be of a temporary nature only. Most analysts expected that unemployment would soon stop rising and with economic recovery unemployment would level off at a relatively low level (Nesporova 2002). However, employment performance did not improve a great deal in most Central and Eastern European Countries (CEECs in the following), though this was partly due to unfavorable developments in world markets. Besides, longer-term effects of structural change in the candidate economies have also played an important role. The countries with the largest expected increases in unemployment - Bulgaria, Poland and Lithuania - were among those with the highest levels. The situation in the individual countries is, of course, highly differentiated, with Hungary and Estonia at the lower bound and Slovakia, Poland and Bulgaria at the upper bound, with unemployment rates exceeding 15 per cent. Yet, in all candidate countries labor markets suffer from structural rigidities that, in combination with continued restructuring, will put a lower limit on reductions in the unemployment rates.

This paper investigates to what extent high exchange rate variability can be made responsible for the negative developments in CEEC labor markets. Previous studies have shown that intra-European exchange rate variability has lowered the volume of trade (see, above all, the impact of exchange rate variability on trade (see, e.g., the early studies by de Grauwe 1987 and Sapir and Sekkat 1990), and has increased unemployment and reduced employment, a finding that had an important bearing on the evaluation of costs and benefits of EMU (see, e.g., Belke and Gros 2001). More recently, Belke and Gros (2002a) have shown in the context of a project for the European Commission that exchange rate variability might also have significant negative effects on labor markets at the global level. Their results indicate that transatlantic exchange rate variability does have a significant negative impact on labor markets in the EU, and possibly also in the US. The authors argue that volatility matters because employment and investment decisions are characterized by some degree of irreversibility in the presence of structural rigidities. Such decisions tend to be discouraged by exchange rate variability, as can be shown in a variety of economic models. A third category of studies is related to the emerging markets. Here, Belke and Gros (2002) have investigated the Mercosur area. 
If similar results can be found for the currencies of the Central and Eastern European EU applicant countries, they would warrant a new look at the costs and benefits of joining EMU or of using early euroization $^{1}$ as a strategy to fulfill the Maastricht criterion of exchange rate stability. The main purpose of this paper is thus to provide a sound basis for an (indirect) evaluation of the costs of the present exchange rate relations of CEEC currencies vis-à-vis the euro and of the benefits of individual time-paths of exchange rate policies for selected CEECs on their way towards full membership in EMU. It is argued that early entry strategies might be motivated with an eye to the benefits resulting from suppressed exchange rate volatility.

The conventional view of EMU enlargement is to converge first, and durably, and then join. For the eight CEE Countries scheduled to join the EU in May 2004 the time frame for EMU enlargement is, thus, quite clear: EU admission also formally implies membership in EMU. Initially, however, the new EU members will have a right of derogation concerning the introduction of the euro. When can and should derogation be lifted, i.e. when should the euro be introduced in these countries? And how can it be ensured that the transition to the euro is smooth? The earliest possible date of entry into the eurozone is 2006, if the EU's new member states spend the prescribed two years in the ERM2 system immediately after EU accession. ${ }^{2}$ A number of the acceding countries (e.g. the Baltic States and Slovenia) have indeed expressed a willingness to proceed to the eurozone as quickly as possible. Other countries such as the Czech Republic, Hungary and Poland are more skeptical concerning a rapid adoption of the euro.

Let us now provide a picture of the development of CEEC trade integration. In general, the CEECs are small, open economies. In most CEECs, external trade (imports and exports) accounts for above one third of GDP, in countries such as Slovenia (67\%) or Estonia (58\%) the degree of openness even exceeds 50\% of GDP. Only Bulgaria (23\%), Romania (15\%) and, due to its larger size, Poland (26\%) have a somewhat smaller openness index (Buiter and Grafe 2002). Boreiko (2002) demonstrates the importance of trade with EMU countries for the CEECs, relating imports and exports to the eurozone to total imports and exports in $1993-2000$. His tables show clearly that most of the CEECs have already reached a high share of trade with the eurozone. In some cases such as Hungary (0.70), Poland (0.67), Slovenia (0.67), and the Czech Republic (0.66) - the shares are close to the average of EMU intra-trade (around 0.67 in 1999-2000). The realizations for the

\footnotetext{
${ }^{1}$ Euroization is defined as the wholesale unilateral adoption of the euro (Nuti 2002, p. 434). For surveys on the costs and benefits of euroization see Alesina and Barro (2001, pp. 381 ff.) and Nuti (2002).

${ }^{2}$ However, due to technical and logistic reasons, it can realistically be expected that the candidate countries will join the eurozone at the earliest in 2007 (see, e.g., Lavrac 2003).
} 
other candidate countries are lower (Romania: 0.63, Estonia: 0.59, Slovak Republic: 0.54, Latvia: 0.52, Bulgaria: 0.50, Lithuania: 0.46). These differences in openness should be kept in mind for the empirical analysis, since they should of course influence the impact of euro exchange rate variability on the labor markets in the respective candidate country. The same is valid for the average degree of openness of the CEECs and the results expected from a pooled regression analysis.

The rest of the paper proceeds as follows: In section 2 we derive a theoretical model to illustrate the negative relationship between exchange rate volatility and labor market performance. Section 3 defines our measure of exchange rate variability. Section 4 presents and comments the regression results. Section 5 concludes with a discussion of the implications of our results for the design of future CEEC monetary relations with the eurozone.

\section{Modeling the impact of exchange rate volatility on labor markets}

\subsection{Motivation}

Most economists would probably assume that exchange rate variability cannot have a significant impact on labor markets, given that the link between exchange rate variability and the volume of trade is known to be weak. However, we would argue that there are some qualifications to such a conclusion: in developing countries the level and variability of the exchange rate may be more important than in developed countries. There are several reasons why exchange rate volatility should have a strong negative impact on emerging economies and, hence, may constitute the basis for the fear of large exchange rate swings (Calvo and Reinhart 2000).

First, the pattern of trade invoicing is different in emerging markets as compared to that in industrial countries. Following McKinnon (1999), primary commodities are primarily dollar invoiced. Since the emerging market economies exports generally have a high primary commodity content, exchange rate volatility should have a significant impact on foreign trade of these countries. Additionally, capital markets in emerging markets are of an incomplete nature. ${ }^{3}$ If futures markets are either illiquid or even nonexistent, tools for hedging the exchange rate risk are simply not available in these countries. Another feature why emerging markets are on average more intolerant to large exchange rate fluctuations is due to the higher openness of these countries. When imports

\footnotetext{
${ }^{3}$ This argument is less important for countries with more efficient financial markets like Czech Republic, Hungary and Poland. However, problems that erupted in the Czech and Hungarian banking sector over the last years indicate that these countries are still vulnerable to speculative attacks - especially in the context of an elimination of all capital controls as is required by the acquis communautaire (Begg et al., 2001, NBH, 2002).
} 
make up a large share of the domestic consumption basket, the pass-through from exchange rate swings to inflation is much higher (Calvo and Reinhart 2000, pp. 18 ff.).

In the following section we develop a full-fledged model to illustrate a mechanism that explains a negative relationship between exchange rate uncertainty and job creation. ${ }^{4}$ This model has originally been based on the idea that uncertainty of future earnings raises the 'option value of waiting' with decisions which concern investment projects in general (Dixit 1989, Belke and Gros 2001). The model does not pretend to be close to reality. It is designed to convey the basic idea in a simple way. Moreover, our intention is to present a model that allows us to ask whether even a temporary, short-run increase in uncertainty can have a strong and lasting impact on employment, and in how far this impact depends on labor market parameters.

\subsection{Scenario A: Modeling with binding contracts}

Consider a set-up in which there are three periods and a single firm active in an export-oriented industry decides about job creation. During the first two periods (called 0 and 1 ) the firm can open a job, hire a worker and produce output that is sold in a foreign market during the following periods. If the job is created during period 0 , the worker is hired for two periods $(0$ and 1$)$ to produce output to be sold in periods 1 and 2. If the job is created in period 1, the worker is hired only for period 1 and output is sold in period 2 .

To create a job, the firm pays a start-up $\operatorname{cost} c$, which reflects the cost of hiring, training and the provision of job-specific capital. After a job is created, a worker is hired and is paid a wage $w$ above the worker's fallback (or reservation) wage $\underline{w}$ during every period of employment. The fallback wage measures (besides disutility of work) all opportunity income that the worker has to give up by accepting the job. In particular, it includes unemployment benefits, but it might also be positively related to a collective wage set by a trade union or to a minimum wage, both of which should raise the worker's fallback position. In general, we would argue that the fallback wage should be higher in countries that are characterized by generous unemployment benefit systems, by strong trade unions or by minimum wage legislation.

In every period in which the worker is employed, he produces output to be sold in the following period in a foreign market at domestic price $p$ which has a certain component $p^{*}$ (the foreign price) plus a stochastic component $e$ (the exchange rate). We assume that the foreign price is fixed

\footnotetext{
${ }^{4}$ For a similar model that analyses the effect of exchange rate uncertainty on investment and not explicitly on the labor market, see Belke and Gros (2001).
} 
('pricing to market'), and that the exchange rate follows a random walk. In period 1, the exchange rate $e_{1}$ is uniformly distributed between $-\sigma_{1}$ and $+\sigma_{1}$. The exchange rate in period $2, e_{2}$, is uniformly distributed between $e_{1}-\sigma_{2}$ and $e_{1}+\sigma_{2}$. An increase in $\sigma_{i}$ means an increase in uncertainty, or an increase in the mean preserving spread in period $i=1,2\left(\sigma_{i}\right.$ is proportional to the standard deviation of $e_{i}$ ). Uncertainty can be temporary (e.g. if $\sigma_{1}>0$ and $\sigma_{2}=0$ ) or persistent (if also $\sigma_{2}>0$ ). As will become apparent soon, however, the variability of the exchange rate during the second period has no influence on the result.

The wage rate $w$ for the job is determined by the (generalized) Nash bargaining solution that maximizes a weighted product of the worker's and the firm's expected net return from the job. We assume that both the firm and the worker are risk-neutral. This assumption implies that risk-sharing issues are of no importance for our analysis. Thus we may assume realistically (but without loss of generality) that the worker and the firm bargain about a fixed wage rate $w$ (which is independent of realizations of the exchange rate) when the worker is hired, so that the firm bears all the exchange rate risk. A wage contract which shifts some exchange rate risk to the worker would leave the (unconditional) expected net returns unaffected, and has therefore no effect on the job creation decision. Of course, if the firm were risk-averse, the assumption that the firm bears all exchange rate risk would make a postponement of job creation in the presence of uncertainty even more likely.

Consider first the wage bargaining problem for a job created in period 0 in which case the worker is hired for two periods. After the job is created (and the job creation cost is sunk), the (unconditional) expected net return of this job is equal to $E_{0}\left(S_{0}\right)=2 p^{*}-2 \underline{w}=2 \pi$ where $\pi=p^{*}-\underline{w}$ denotes the expected return of a filled job per period (we abstract from discounting). Denoting the bargaining power of the worker by $0<\beta<1$, the firm's net return from the job created in period 0 is ${ }^{5}$

$$
\mathrm{E}_{0}\left(\Pi_{0}\right)=(1-\beta) \mathrm{E}_{0}\left(\mathrm{~S}_{0}\right)-\mathrm{c}=2(1-\beta) \pi-\mathrm{c}
$$

In order to make the problem non-trivial, the expected return from job creation in period 0 must be positive, i.e. we assume that $2(1-\beta) \pi-c>0$. Implicit in our model is the assumption that the firm and the worker sign a binding employment contract for two periods (0 and 1). Hence, job termination is not an option in case the exchange rate turns out to be unfavorable. In period 1 (after

\footnotetext{
${ }^{5}$ The wage bargain leads to a wage rate maximizing the Nash product $(2 w-2 \underline{w})^{\beta}\left(2 p^{*}-2 w\right)^{1-\beta}$ whose solution is $w=(1-$ $\beta) \underline{w}+\beta p^{*}$. Hence the expected net return for the firm is $2 p^{*}-2 w-c=(1-\beta)\left(2 p^{*}-2 \underline{w}\right)-c$.
} 
realization of the exchange rate) the conditional expected surplus from job continuation is $E_{1}\left(S_{1}\right)=\pi+e_{1}$ which may be negative if the exchange rate falls below $-\pi<0$.

If the firm waits until period 1, it keeps the option of whether or not to open a job. It will create a job only if the exchange rate realized during period 1 (and so expected for period 2) is above a certain threshold level, or barrier, denoted by $b$. Given that employment in period 1 yields a return in period 2 only, this profitability barrier is defined by the condition that the (conditional) expected net return to the firm is zero:

$$
(1-\beta)\left(p^{*}+b-\underline{w}\right)-c=0 \text { or } b=c /(1-\beta)+\underline{w}-p^{*}=c /(1-\beta)-\pi
$$

Whenever $e_{1} \geq b$, the firm creates a job in period 1, and the conditional expected net return to the firm is $E_{1}\left(\Pi_{1}\right)=(1-\beta)\left(\pi+e_{1}\right)-c \geq 0$. Whenever $e_{1}<b$, the firm does not create a job in period 1 , and its return is zero. Hence, whenever both events occur with positive probabilities (i.e. whenever $\sigma_{l}>$ $\left.b>-\sigma_{1}\right)^{6}$, the unconditional expected return of waiting in period 0 is given by:

$$
E_{0}\left(\Pi_{1}\right)=\left[\left(\sigma_{1}+b\right) /\left(2 \sigma_{l}\right)\right] 0+\left[\left(\sigma_{l}-b\right) /\left(2 \sigma_{l}\right)\right]\left[(1-\beta)\left(\pi+\left(\sigma_{l}+b\right) / 2\right)-c\right]
$$

where the first element is the probability that it will not be worthwhile to open a job (in this case the return is zero). The second term represents the product of the probability that it will be worthwhile to open the job (because the exchange rate is above the barrier) and the average expected value of the net return to the firm under this outcome. Given condition (2) this can be rewritten as:

$$
E_{0}\left(\Pi_{l}\right)=(1-\beta)\left(\sigma_{l}-b\right)^{2} /\left(4 \sigma_{l}\right)
$$

This is the key result since it implies that an increase in uncertainty increases the value of waiting, given that equation (4) is an increasing function of $\sigma_{l}{ }^{7}$ As $\sigma_{l}$ increases it becomes more likely that it is worthwhile to wait until more information is available about the expected return during period 2. The option not to open the job becomes more valuable with more uncertainty. The higher the variance the higher the potential losses the firm can avoid and the higher the potential for a very

\footnotetext{
${ }^{6}$ We do not a priori restrict the sign of the barrier $b$. Hence one of these conditions is automatically satisfied, whereas the other is satisfied only if uncertainty is large enough.

${ }^{7}$ Formally this results from the fact that equation (4) is only valid whenever $\sigma_{l}$ exceeds $b$ (otherwise the exchange rate could never exceed the barrier and the firm never creates a job in period 1) and whenever $-\sigma_{1}$ is lower than $b$ (otherwise the exchange rate could never fall below the barrier and the firm always creates a job in period 1).
} 
favorable realization of the exchange rate, with consequently very high profits. It is clear from (1) and (4) that the firm prefers to wait if and only if

$$
(1-\beta)\left(\sigma_{l}-b\right)^{2} /\left(4 \sigma_{l}\right)>2(1-\beta) \pi-c .
$$

As the left hand side is increasing in $\sigma_{1}$, the firm delays job creation if exchange rate uncertainty is large enough. The critical value at which (5) is satisfied with equality can be solved as ${ }^{8}$

$$
\sigma_{1}^{*}=3 \pi-c /(1-\beta)+2 \sqrt{\pi(2 \pi-c /(1-\beta))} .
$$

Whenever $\sigma_{l}>\sigma_{l}{ }^{*}$, firms decide to postpone job creation in period 0 . Since $\sigma_{l}{ }^{*}$ is increasing in $\pi$ (and thereby decreasing in the fallback wage $\underline{w}$ ), decreasing in the cost of job creation $c$ and decreasing in the worker's bargaining power $\beta$, we conclude that a strong position of workers in the wage bargain (reflected in a high fallback wage or in the bargaining power parameter) and higher costs of hiring raise the option value of waiting and make a postponement of job creation more likely. Thus, the adverse impact of exchange rate uncertainty on job creation and employment should be stronger if the labor market is characterized by generous unemployment benefit systems, powerful trade unions, minimum wage restrictions or large hiring costs. The adverse employment effects of these features have been confirmed empirically in various studies, and there are many other theoretical mechanisms to explain them (see, e.g., Nickell 1997). What our simple model shows is that these features also reinforce the negative employment effects of contemporaneous and short spikes of exchange rate uncertainty. In sum, we retain two conclusions from the model. First, even a temporary spike in exchange rate variability can induce firms to wait with their creation of jobs (for exactly this reason, the level of the exchange rate at the same time loses explanatory power). Second, the relationship between exchange rate variability and employment should be particularly strong, if the labor market is characterized by rigidities that improve the bargaining position of workers. A stronger fallback position of workers raises the contract wage, lowers the net returns to firms and induces firms to delay job creation in the face of uncertainty.

\subsection{Scenario B: Modeling without binding contracts}

Our argument in section 2.2 rests on the assumption that workers cannot be fired immediately if the exchange rate turns out to be unfavorable. Hence, sunk wage payments are associated with the decision to hire a worker. These sunk costs and, consequently, the impact of uncertainty on job

\footnotetext{
${ }^{8}$ The other (smaller) solution to this equation is less than $|b|$ and is therefore not feasible.
} 
creation become more important if there are high firing costs. However, as we would, even if there are no firing costs and if workers can be laid off at any point in time, exchange rate uncertainty should have a direct impact on job destruction. To illustrate this proposition, consider the scenario of a labor market in which the firm and the worker can sign a contract only for one period and keep the option to terminate the work relationship whenever it becomes unprofitable. In period 1, the conditionally expected surplus of job continuation is $\pi+\mathrm{e}_{1}$ which is positive whenever $\mathrm{e}_{1}>-\pi$. Hence, whenever uncertainty is large enough $\left(\sigma_{1}>\pi\right)$, there is job destruction in period 1 with probability $\left(\sigma_{1}-\pi\right) /\left(2 \sigma_{1}\right)$. The (unconditional) expected net return to the firm from a job created in period zero (and with the option of destruction in period one) is therefore

$$
\left.\mathrm{E}_{0}\left(\Pi_{0}\right)=[(1-\beta) \pi-\mathrm{c}]+\left[\left(\sigma_{1}-\pi\right) / 2 \sigma_{1}\right] 0+\left[\left(\sigma_{1}+\pi\right) / 2 \sigma_{1}\right](1-\beta)\left[\pi+\left(\sigma_{1}-\pi\right) / 2\right)\right],
$$

where the first term is the expected return from the job in period one, whereas the second and third term represent the expected surplus from the job in period two (after destruction or after continuation in period one) under the assumption $\sigma_{1}>\pi$. If $\sigma_{1}<\pi$, the job would never be destroyed, and the expected net return is, as before, $2(1-\beta) \pi-c$. Hence, after rearranging (7), the expected net return from a job created in period zero can be written

$$
\mathrm{E}_{0}\left(\Pi_{0}\right)=\left\{\begin{array}{l}
2(1-\beta) \pi-\mathrm{c}, \text { if } \sigma_{1}<\pi, \\
(1-\beta)\left(\pi+\left(\sigma_{1}+\pi\right)^{2} /\left(4 \sigma_{1}\right)\right)-\mathrm{c}, \text { if } \sigma_{1} \geq \pi .
\end{array}\right.
$$

On the other hand, if the firm waits until period 1, the (unconditional) expected net return is, as in Section 2.2,

$$
\mathrm{E}_{0}\left(\Pi_{1}\right)=\left\{\begin{array}{l}
\max (0,(1-\beta) \pi-\mathrm{c}), \text { if } \sigma_{1}<|\pi-\mathrm{c} /(1-\beta)| \\
(1-\beta)\left(\sigma_{1}+\pi-\mathrm{c} /(1-\beta)\right)^{2} /\left(4 \sigma_{1}\right), \text { if } \sigma_{1} \geq|\pi-\mathrm{c} /(1-\beta)|
\end{array}\right.
$$

It is now easy to see that the firm never delays job creation. First, if $\sigma_{1} \leq|\pi-\mathrm{c} /(1-\beta)|<\pi$, the firm never destroys a job in period 1 , and so we have $E_{0}\left(\Pi_{0}\right)>E_{0}\left(\Pi_{1}\right)$. Second, if $\sigma_{1} \geq \pi$, the condition $\mathrm{E}_{0}\left(\Pi_{0}\right)>\mathrm{E}_{0}\left(\Pi_{1}\right)$ means that

$$
4 \sigma_{1}(\pi-\mathrm{c} /(1-\beta))+\left(\sigma_{1}+\pi\right)^{2}>\left(\sigma_{1}+\pi-\mathrm{c} /(1-\beta)\right)^{2}
$$

which turns out to be equivalent to $(2(1-\beta) \pi-c)\left(c /(1-\beta)+2 \sigma_{1}\right)>0$ and which is satisfied because of our assumption $2(1-\beta) \pi-c>0$. Hence, the firm does not delay job creation also in this case. Finally, if $|\pi-\mathrm{c} /(1-\beta)|<\sigma_{1}<\pi$, the condition $\mathrm{E}_{0}\left(\Pi_{0}\right)>\mathrm{E}_{0}\left(\Pi_{1}\right)$ means that 


$$
4 \sigma_{1}(2(1-\beta) \pi-c)-(1-\beta)\left(\sigma_{1}+\pi-c /(1-\beta)\right)^{2}>0 \text {. }
$$

But since this inequality is satisfied at the boundaries $\sigma_{1}=\pi$ and $\sigma_{1}=|\pi-\mathrm{c} /(1-\beta)|$ and since the left hand side is a concave function of $\sigma_{1}$, the inequality is also satisfied in the interval $|\pi-c /(1-\beta)|<$ $\sigma_{1}<\pi$. Hence, firms always prefer to create a job in period zero, and so exchange rate uncertainty has no impact on job creation.

However, since there is job destruction with probability $(\sigma 1-\pi) /(2 \sigma 1)$ (whenever $\sigma 1>\pi$ ), the probability of job destruction is increasing in uncertainty. Hence, there is also a negative impact of exchange rate uncertainty on employment in this case. Moreover, this effect is more pronounced if the worker's fallback wage is higher (if $\pi$ is smaller). Therefore, the basic conclusions of our model remain valid. Thus, we can show that, perhaps against common intuition (but as an additional interesting innovation of our paper), uncertainty does not lead to delays but to spurts in the decision to fire. In contrast to the usual models of investment under uncertainty of the Dixit-Pindyck style, the impacts of increased uncertainty on employment are unambiguously negative and can be directly tested empirically.

\subsection{Does the model apply to the CEEC labor markets?}

According to our model, the relationship between exchange rate variability and employment should be particularly strong if the labor market is characterized by rigidities that, e.g., improve the bargaining position of workers. Labor markets of most of the current EU members are widely considered to be rigid enough to give leeway to the functioning of the mechanism explained in the model. Where do the candidates stand in this respect?

Riboud, Sánchez-Páramo, Silva-Jáuregui (2002) have assessed the flexibility of labor market institutions in six CEE candidate countries: the Czech Republic, Estonia, Hungary, Poland, Slovakia and Slovenia. ${ }^{9}$ According to their findings based on a large scale of indicators for regular contracts, temporary contracts and collective dismissals, these countries range somewhere in the middle of the flexibility scale compared to the OECD economies. They do not reach the levels of flexibility of the UK, Ireland and Denmark, but exhibit much greater flexibility than the Club Med countries, France and Germany. ${ }^{10}$ As regards the unemployment insurance systems, the CEECs seem to be less

\footnotetext{
${ }^{9}$ In order to allow for a comparison with the developed economies the authors made use of the OECD methodology (1994 and 1999).

${ }^{10}$ See our Table 1 and Riboud et. al. 2002, pp. 7 f. However, in terms of employment protection legislation, Slovenia belongs to those countries with the highest degree of inflexibility. This could change if the new proposed labor code
} 
generous than the OECD or the EU countries. They also spend less on both passive and active employment policies. In terms of the role of the unions in the wage negotiation process, the candidates range somewhere in the middle of the OECD countries. They have, however, extremely high payroll and other taxes, which exceed even the highest levels in the EU. Even more important in our context is the fact that they have strong employment protection legislation (see Table 1).

These results are consistent with findings by Belke and Hebler (2002) and Cazes (2002) who state that Central European Countries have adopted labor market institutions, institutional arrangements and legal frameworks that share many common features with present EU Member Countries. This trend clearly increases job creation costs. It is further supported by the fact that the CEECs are required, prior to their entry into the EU, to align their legislation with the acquis communautaire, which includes a number of provisions regarding labor market regulations. This kind of legislation has favored employment protection while taxing employers heavily. Hence, the transmission channel from exchange rate variability to labor market performance that we have described seems to be relevant in the case of the CEECs also.

Table 1: Labour market flexibility in the CEECs: How large are the costs of job creation and the fallback wage?

\begin{tabular}{|c|c|c|c|c|c|c|c|c|}
\hline & \multicolumn{4}{|c|}{ Employment protection legislation $* * *$} & \multicolumn{2}{|c|}{$\begin{array}{c}\text { Unemployment } \\
\text { insurance }\end{array}$} & \multicolumn{2}{|c|}{ Taxes } \\
\hline & $\begin{array}{l}\text { Regular } \\
\text { empl. }\end{array}$ & $\begin{array}{c}\text { Temporary } \\
\text { empl. }\end{array}$ & $\begin{array}{l}\text { Collective } \\
\text { dismissals }\end{array}$ & \begin{tabular}{|c|} 
EPL \\
Strictness \\
$* * * *$
\end{tabular} & $\begin{array}{c}\text { Benefit } \\
\text { replace- } \\
\text { ment ratio }\end{array}$ & $\begin{array}{c}\text { Benefit } \\
\text { duration } \\
\text { (months) }\end{array}$ & $\begin{array}{c}\text { Payroll } \\
\text { tax rate } \\
(\%)\end{array}$ & $\begin{array}{l}\text { Total tax } \\
\text { rate }(\%)\end{array}$ \\
\hline $\begin{array}{l}\text { Czech } \\
\text { Republic } \\
\end{array}$ & 2.8 & 0.5 & 4.3 & 2.1 & 50 & 6 & 47.5 & 73.4 \\
\hline Estonia & 3.1 & 1.4 & 4.1 & 2.6 & 10 & $3-6$ & 33.0 & 63.3 \\
\hline Hungary & 2.1 & 0.6 & 3.4 & 1.7 & 64 & 12 & 44.0 & 81.5 \\
\hline Poland & 2.2 & 1 & 3.9 & 2 & 40 & $12-24$ & 48.2 & 80.0 \\
\hline Slovakia & 2.6 & 1.4 & 4.4 & 2.4 & 60 & $6-12$ & 50.0 & 81.0 \\
\hline Slovenia* & $3.4(2.9)$ & $2.4(0.6)$ & $4.8(4.9)$ & $3.5(2.3)$ & 63 & $3-24$ & 38.0 & 69.1 \\
\hline $\begin{array}{l}\text { CEEC } \\
\text { average }\end{array}$ & 2.7 & 1.2 & 4.1 & 2.4 & 48 & & 43.4 & 74.7 \\
\hline $\begin{array}{l}\text { EU } \\
\text { average** }\end{array}$ & 2.4 & 2.1 & 3.2 & 2.4 & 60 & & 23.5 & 53.0 \\
\hline $\begin{array}{l}\text { OECD } \\
\text { average }\end{array}$ & 2.0 & 1.7 & 2.9 & 2.0 & 58 & & 19.5 & 45.4 \\
\hline
\end{tabular}

* Numbers in brackets refer to the new labour code if approved

** EU average without Luxembourg and Greece

*** 1: minimum protection, 6: maximum protection

$* * * * \quad$ Weighted average of the first three columns 
Table 1: continued

\begin{tabular}{|c|c|c|c|c|c|c|c|c|}
\hline & Pass & ve policies & Acti & ve policies & & & Jnions & \\
\hline & $\begin{array}{l}\% \text { of } \\
\text { GDP }\end{array}$ & $\begin{array}{l}\text { Spending per } \\
\text { unemployed }\end{array}$ & $\begin{array}{l}\% \text { of } \\
\text { GDP }\end{array}$ & $\begin{array}{l}\text { Spending per } \\
\text { unemployed }\end{array}$ & $\begin{array}{l}\text { Union } \\
\text { density } \\
(\%)^{*}\end{array}$ & $\begin{array}{c}\text { Union } \\
\text { coverage } \\
\text { index }{ }^{* *}\end{array}$ & \begin{tabular}{|c|} 
Coordinat \\
ion- \\
unions \\
\end{tabular} & $\begin{array}{l}\text { Coordinatio } \\
\text { n-employers }\end{array}$ \\
\hline \begin{tabular}{l|} 
Czech \\
Republic
\end{tabular} & 0.31 & 0.04 & 0.19 & 0.02 & 42.8 & 2 & 1 & 1 \\
\hline Estonia & 0.08 & 0.01 & 0.08 & 0.01 & 36.1 & 2 & 2 & 1 \\
\hline Hungary & 0.56 & 0.06 & 0.40 & 0.04 & 60.0 & 3 & 1 & 2 \\
\hline Poland & 1.71 & 0.12 & 0.49 & 0.03 & 33.8 & 3 & 2 & 1 \\
\hline Slovakia & 0.54 & 0.05 & 0.56 & 0.05 & 61.7 & 3 & 2 & 2 \\
\hline Slovenia & 0.89 & 0.11 & 0.83 & 0.11 & 60.0 & 3 & 3 & 3 \\
\hline \begin{tabular}{|l|} 
CEEC \\
average
\end{tabular} & 0.68 & 0.06 & 0.42 & 0.04 & 49.0 & & & \\
\hline EU average & 1.73 & 0.26 & 1.16 & 0.16 & 44.4 & & & \\
\hline $\begin{array}{l}\text { OECD } \\
\text { average }\end{array}$ & 1.43 & 0.23 & 0.92 & 0.14 & 39.6 & & & \\
\hline
\end{tabular}

The next step is to address whether different measures of exchange rate volatility - both nominal and real effective volatility vis-à-vis the 31 most important trade partners and the bilateral volatility of the nominal and real euro exchange rate - have any ability to explain the residuals of employment regressions for CEEC economies. Up to now, the literature examining the link between exchange rate variability and labor market performance in emerging markets is rather thin. Hence, we begin by presenting and commenting on some initial results.

\section{Data and Definitions}

In order to test empirically for the conjectured impact of exchange rate variability on labor-market performance, we employ a panel of ten Central and Eastern European Countries, namely Bulgaria (BG), Czech Republic (CZ), Estonia (EE), Hungary (HU), Latvia (LV), Lithuania (LT), Poland (PL), Romania (RO), Slovak Republic (SK), Slovenia (SL). We do not leave the two EU latecomers Bulgaria and Romania aside, because Bulgaria, at least, is often said to be a clear case for euroization.

The nominal variability of the currency of each of the ten CEE Countries, which have applied for EU membership, is measured by taking for each year the standard deviation of the 12 month-tomonth changes in the logarithm of its nominal exchange rate against the currencies of their main trade partner countries. The construction of the real variability variable follows an analogous scheme. The nominal exchange rates are deflated with the CPI. The standard deviations based on 
bilateral rates are then aggregated in one composite measure of exchange rate variability (denoted by "VOL" below) using the weights that approximate the importance of these currencies in trade with the 31 most important trade partners for the period 1993-2002. The average trade weight of CEEC X with country Y (Y = Austria, Belgium, Denmark, Finland, France, Germany, Greece, Ireland, Italy, Netherlands, Portugal, Spain, Sweden, UK, Bulgaria, Czech Republic, Estonia, Hungary, Latvia, Lithuania, Poland, Romania, Slovakia, Slovenia, Croatia, Belarus, Russia, Ukraine, Switzerland, U.S., Turkey) is calculated as 100 times the exports to country Y plus imports from country Y divided by total exports to the "world" plus total imports from the "world". In our definition, the aggregate "world" corresponds to the sum of countries Y. ${ }^{11}$ We did not use the annually changing trade weights since our volatility measure would then change to the same degree as the change in trade pattern varies.

Based on the monthly CPI series for the 31 most important trade partners, the nominal bilateral exchange rates vis-à-vis the U.S.-dollar of these countries and the respective trade weights, we calculated the following volatilities of the exchange rate:

- 10 times 30 volatilities of the nominal bilateral exchange rate,

- 10 times 30 volatilities of the real bilateral exchange rate,

- 10 effective volatilities of the nominal exchange rate (weighted bilateral volatilities), and

- 10 effective volatilities of the real exchange rate (weighted bilateral volatilities).

It should be emphasized that the first two series refer to the exchange rate volatility "vis-à-vis the euro". This is calculated as the volatility vis-à-vis the DM from 1992:01 until 1998:12, and vis-à-vis the euro from 1999:01. We prefer to aggregate the individual standard deviations instead of using a standard deviation of an average or effective exchange rate because there is extensive evidence that CEEC exporters have priced to market. With an average exchange rate the zloty, for example, could remain constant because the depreciation against the euro would compensate the appreciation against the Bulgarian lewa. Polish firms would not necessarily be indifferent between a situation in which the average exchange rate is constant because the zloty/euro and the zloty/lewa are constant, and another in which the swings in these two bilateral rates just happen to cancel each other out.

\footnotetext{
${ }^{11}$ It should be noted that trade data for Euroland substitute the data for the single euro zone member countries from 1999 on.
} 
We use monthly exchange rates to calculate volatility instead of daily volatility to ensure consistency throughout our entire sample period. Another reason to prefer this measure to shorterterm alternatives (e.g., daily variability) was that, while the latter might be important for financial actors, they are less relevant for export or employment decisions. The drawback of monthly exchange rates is that we had to use annual data to have a meaningful measure of variability. We are left with only nine observations for each country. ${ }^{12}$

We use actual as opposed to unanticipated rates, since in order to be consistent with our model described in section 2, we assume that the exchange rate follows a random walk. Thus, actual and unanticipated exchange rate changes should be the same. We feel justified to make this assumption since extensive research based on work by Meese and Rogoff (1983) and Meese (1990) has shown that the random walk model outperforms other standard exchange rate models in out-of-sample forecasting. This still holds even when seemingly relevant economic variables are included.

Our sample covers the period 1992 to 2001 in order to exploit all reliable data information. However, in view of the financial turmoil in the first years of transition, our estimations mostly exclude the year 1992. The average exchange rate variability for each of the ten CEECs under investigation is plotted in Figure 1 (per cent per month). Peaks occur usually in the year 1998, with the two non-EU Acceding Countries Bulgaria and Romania as clear outliers with high double-digit realizations. Low volatility values typically appear at the end of the sample, especially in 2000 and 2001. Effective real volatility has decreased for countries that used exchange rate arrangements close to fixed rates, but remained high for Poland and Romania and was quite high for Latvia and Lithuania (for a similar observation see Boreiko 2002, pp. $14 \mathrm{ff}$.). In case of the countries with macroeconomic instability and high inflation, an inspection of our data reveals that the variation in the bilateral real exchange rate is large and much higher than nominal exchange rate variability. This is somewhat surprising given the fact that PPP is usually closer to holding for countries with very high rates of inflation, which would suggest that real exchange rate variability should be smaller. However, it seems obvious that a high real exchange rate variability signals weak macroeconomic management rather than an adjustment need of the real sector.

In contrast to our previous studies and strictly in line with our model we leave out unemployment and limit our empirical analysis to the impact of exchange rate variability on employment. We use the yearly average of employment in thousands.

\footnotetext{
${ }^{12}$ In principle one might employ option prices to extract implicit forward looking volatilities, but option prices are generally available only for the US dollar and sometimes against the DM, and even then only for limited periods.
} 
The existence of a significant in-official sector in the CEECs should not matter too much for regressions if one uses changes of employment. Moreover, data on employment refers of course only on official employment, i.e. those officially declared and thus subject to social security contributions, income tax, and all official labor market regulations. This implies that we not take into account the potentially very large black or underground economy for data availability reasons. The focus on the official labor market is, however, entirely appropriate. In the black economy the cost of firing are presumably much lower because official employment regulations do not apply. This implies that our model of firing costs applies mainly to official employment and we would expect volatility to be mainly a deterrent to official employment. Data on (official) employment is usually much more accurate than data on unemployment, because the definition of who is looking for work, but unable to find it, changes often. Moreover, the geographical coverage of the unemployment statistics changes over time as well. At times the national unemployment data reflect mainly data from one or two major provinces. Employment data, by contrast is usually nation-wide because it encompasses all people on the social security registers.

As a cyclical control variable in the employment equations we include the real growth rate of the gross domestic product, in percent. The development of wage costs is approximated by the real growth rate of average gross monthly wages in percent. With the exception of Estonia, Latvia, Lithuania where we used Eurostat and national sources, the data for employment, GDP growth and wage costs are taken from the CEEC data set compiled by the Vienna Institute for International Economic Studies.

In order to convey a broad-brush view on the data set and some of the possible correlations four scatter plots are presented in Figure 1. It shows cross-plots of our measure for total economy employment growth in percent against exchange rate volatility. All variables are averaged over the period 1993 to 2001.

As expressed by the simple scatter plots relating average employment growth (in percent) to the average volatility measure, there seems to be some first glance evidence that the conjectured negative relationship between exchange rate volatility and employment holds in a cross-country perspective for the CEECs. What matters is that the overall relationship in the figures is downward sloping (non-vertical and non-horizontal). Hence, we fit a very preliminary bivariate regression of average employment growth (in percent) on an average of four different measures of exchange rate variability. In all of these four cases, we cannot reject the hypothesis of a negative relationship according to the fitted regression lines. The example of Estonia shows that the introduction of a 
currency board does not shelter an economy from the negative impact of effective exchange rate variability. The same is valid with respect to Latvia, with its exchange rate fixed to the SDRs.

\section{Figure 1: Employment growth (in \%) and exchange rate volatility}

(10 Central and Eastern European Countries, average 1992 - 2001)

a) Effective nominal exchange rate volatility

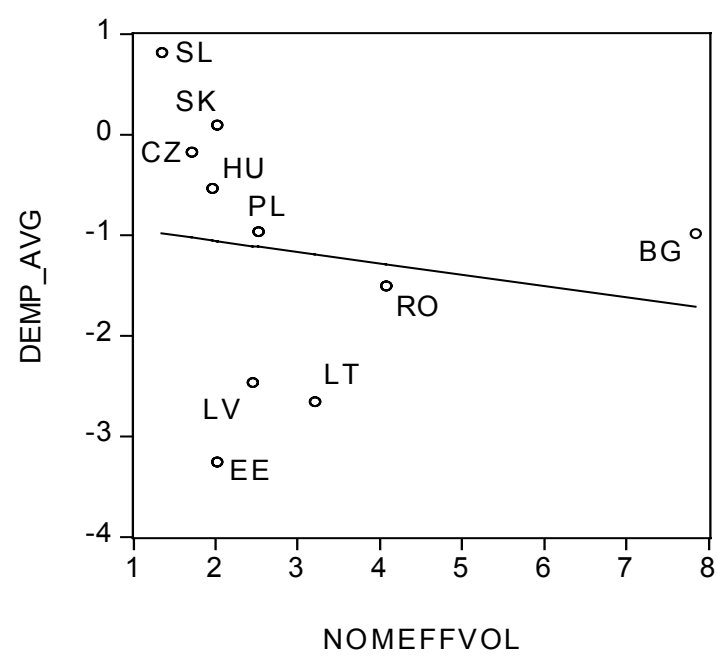

c) Nominal bilateral exchange rate volatility

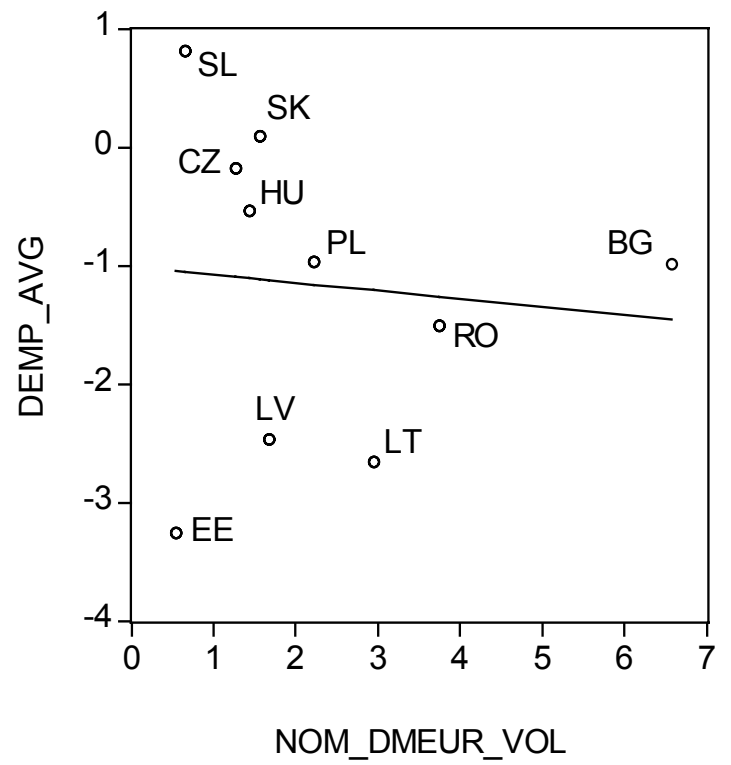

b) Effective real exchange rate volatility

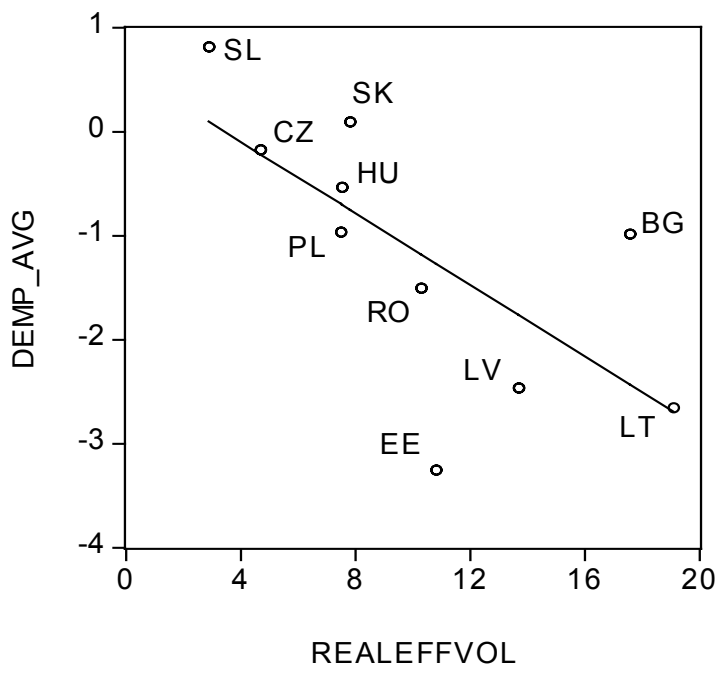

d) Real bilateral exchange rate volatility

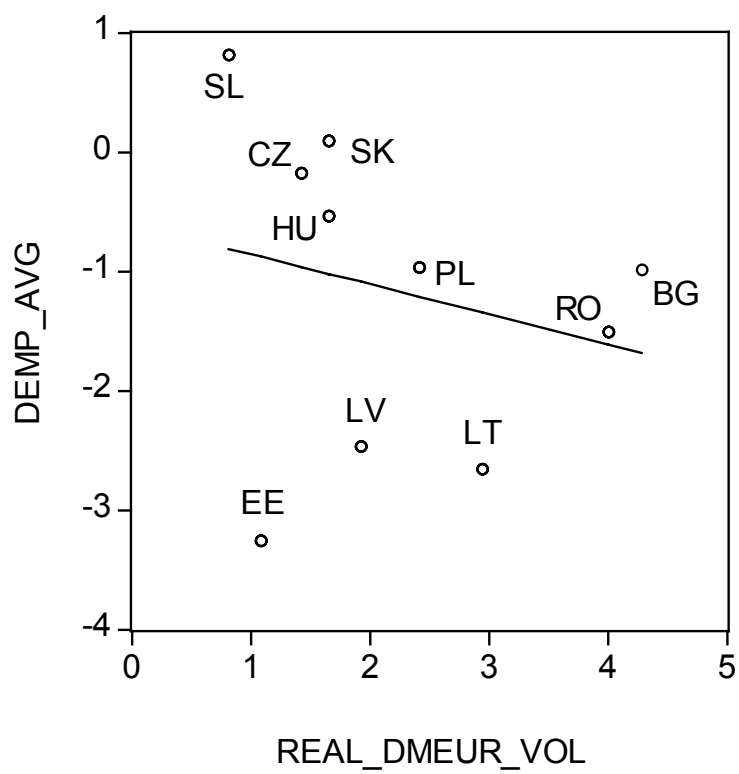


However, in order to investigate the validity of our hypothesis more deeply, we will conduct fully specified regressions in the following section. Our formal empirical analysis is based on tests of the non-stationarity of the levels and the first differences of the variables under consideration, i.e., total economy employment, the different operationalizations of exchange rate volatility, and the real growth rate of average gross monthly wages. ${ }^{13}$ The test applied is the first widely used panel data unit root test by Levin and Lin (1992). The results indicate that only (the log of) employment has to be differenced once to become stationary. That is, we estimate panel regressions for employment growth.

Our unit root tests reveal evidence of a stationary behavior of the levels of exchange rate volatility and of real wage growth. Hence, we use the employment growth and levels of exchange rate volatility in the following pooled estimations.

\section{Empirical Model and Results}

Based on our theoretical arguments, we conjecture that, controlling for the usual key variables on the labor market, ${ }^{14}$ we can show in a cross-country panel analysis of Central and Eastern European countries that exchange rate variability worsens labor-market performance. To test for a significant negative relationship between exchange rate variability and labor-market performance, we undertake a fixed effects estimation. By this, we account for different intercepts and, hence, different natural rates of employment estimated for each CEEC. ${ }^{15}$

In the literature random effects models are sometimes additionally implemented, mainly because fixed effects models and country-dummies are costly in terms of lost degrees of freedom. We decided to dispense with such an exercise, because our sampled cross-sectional units could not be drawn from a large population. Moreover, following our main argument in section 2, there is no reason to assume the country-specific constants in the employment equations as random a priori. Hence, random effects models will probably have to be excluded a priori for many richer specifications of the empirical model also from this perspective.

\footnotetext{
${ }^{13}$ The results of unit root tests for the employment protection legislation index are available on request. It should be kept in mind that the artificial and constructed character of these institutional variables can create serious problems for their correct empirical treatment. Hence, in cases of doubt about the order of integration we do not rely too much on the numerical results but stick to economic intuition when specifying our regression equations.

${ }^{14} \mathrm{We}$ do this by allowing for country-specific constants in the employment regressions or by implementing real wage growth or a labor market protection legislation index.

${ }^{15}$ Due to the limited availability of data for the CEECs with a maximum of 9 annual observations country-specific regressions are not (yet) an option.
} 
However, for reasons of methodological correctness, we also performed Hausman specification tests to check empirically whether fixed effects is the correct estimation procedure (against the possible alternative of random effects). For this purpose, we computed the Hausman test statistic for testing the null hypothesis of random effects against the alternative hypothesis of fixed effects (Hausman 1978, Stata Corporation 2003, pp. 51 ff.). We are concerned with four specifications according to which employment growth is a function of the real GDP growth rate and one of four different measures of exchange rate variability (effective volatility of nominal and real exchange rates and the nominal and real EXR volatility "vis-à-vis the euro"). Moreover, we differentiate between static and dynamic specifications. In our context, "dynamic" means the additional inclusion of the growth of employment lagged two periods as an instrument for the lagged endogenous variable. The results, which reveal overwhelming evidence in favour of a fixed effects estimation, are displayed in the Tables $2 \mathrm{a}$ and $2 \mathrm{~b}$. Hence, we feel legitimised to dispense with random effects estimations and to focus on fixed effects models.

Table 2a: Hausman tests for fixed versus random effects (static specifications)

\begin{tabular}{lll}
\hline Measure of EXR variability used & Test statistics & Empirical realisation \\
\hline Effective volatility of nominal exchange rates & chi-sqr(2)= & 4.04 \\
& p-value $=$ & 0.13 \\
& chi-sqr(2)= & 11.63 \\
Effective volatility of real exchange rates & p-value $=$ & 0.00 \\
& chi-sqr(2) $=$ & 3.73 \\
Nominal EXR volatility "vis-à-vis the euro" & p-value $=$ & 0.15 \\
& chi-sqr(2) $=$ & 4.96 \\
Real EXR volatility “vis-à-vis the euro" & p-value $=$ & 0.08 \\
\hline
\end{tabular}


Table 2b: Hausman tests for fixed versus random effects (dynamic specifications)

\begin{tabular}{lll}
\hline Measure of EXR variability used & Test statistics & Empirical realisation \\
\hline Effective volatility of nominal exchange rates & chi-sqr(2)= & 17.30 \\
& p-value $=$ & 0.00 \\
& chi-sqr(2)= & 21.13 \\
Effective volatility of real exchange rates & p-value $=$ & 0.00 \\
& chi-sqr(2) $=$ & 11.83 \\
Nominal EXR volatility "vis-à-vis the euro" & p-value $=$ & 0.01 \\
& chi-sqr(2) $=$ & 18.98 \\
Real EXR volatility “vis-à-vis the euro" & p-value $=$ & 0.00 \\
\hline
\end{tabular}

The empirical model we use can now be described by the usual form: ${ }^{16}$

$$
y_{i t}=\alpha_{i}+x_{i t}^{\prime} \beta_{i}+\varepsilon_{i t}
$$

with $y_{i t}$ as the dependent (macroeconomic labor market) variable, $x_{i t}$ and $\beta_{i}$ as k-vectors of nonconstant regressors (e.g., exchange rate variability) and parameters for $i=1,2, \ldots, N$ cross-sectional units and $t=1,2, \ldots, T$ as the periods for which each cross-section is observed. Imposing $\alpha_{i}=\alpha_{j}=$ $\alpha$, a pooled analysis with common constants is nested in this specification.

In order to test for significance of the impact of exchange rate volatility on labor-market performance in CEECs, we separate our analysis into three logical steps. We note that basing the analysis on levels of employment as an endogenous lagged variable is problematic for, at least, two reasons. First, employment time series might be plagued by non-stationarity problems (see section 3). Second, one has to take account of the well-known problem of endogenous lagged variables in the context of panel analyses (group effects). This is usually achieved by taking first differences, which is a further reason why we conducted our analysis in these terms. Third, the theoretical

\footnotetext{
${ }^{16}$ Dummies for different exchange rate regimes are not included throughout the regressions since the impact of different exchange rate regime on the labor market is exactly the focus of our study.
} 
interest is in a link between the level of exchange rate volatility and the growth of employment. According to this specification, a one-time shock in exchange rate volatility results in a permanent reduction of the employment level. This exactly mirrors the central persistence implication of the model which postulates that even a short-term increase in exchange rate uncertainty leads to less hiring and more firing. The dynamic implications of our specification are thus acceptable for temporary shocks, i.e. spikes, in exchange rate variability, which were emphasized in our model.

In principle, our panel data set need not be applied to a static specification (in the following tables this corresponds to the first column for each volatility measure). Especially with respect to the wellknown path-dependence of employment, it is advisable to test for dynamic effects also. In order to capture the speed of adjustment of labor markets, we use the option to include lagged employment variables in the set of regressors throughout this paper. The corresponding setting with respect to a representative regression equation for one cross-section out of the whole system (described by the index $i$ ) can be described as follows:

$$
y_{i t}=\alpha_{i}+x_{i t}^{\prime} \beta_{i}+\delta y_{i, t-1}+\varepsilon_{i t}
$$

However, for estimating our first-order model substantial complications have to be taken into account. Problems arise due to the heterogeneity of the cross-sections analyzed (Greene 2000, pp. $582 \mathrm{ff}$ ). The main problem to be treated here is the correlation of the lagged dependent variable 'level of employment' with the disturbance, even if the latter does not exhibit autocorrelation itself. While taking first differences enables one to get rid of heterogeneity, i.e., the group effects, the problem of the correlation between the lagged dependent variable and the disturbance still remains. Moreover, a moving-average error term now appears in the specification. However, the treatment of the resulting model is a standard application of the instrumental variables approach. The transformed model looks as follows:

$$
y_{i t}-y_{i, t-1}=\left(x_{i t}-x_{i, t-1}\right)^{\prime} \beta_{i}+\delta\left(y_{i, t-1}-y_{i, t-2}\right)+\left(\varepsilon_{i t}-\varepsilon_{i, t-1}\right)
$$

Arellano (1989) and Greene (2000) for instance recommend using the differences $\left(y_{i, t-2}-y_{i, t-3}\right)$ or the lagged levels $y_{i, t-2}$ and $y_{i, t-3}$ as instrumental variables for $\left(y_{i, t-1}-y_{i, t-2}\right)$ in order to derive a simple instrumental variable estimator. The remaining variables can be taken as their own instruments. Arellano (1989) gives some theoretical and empirical support in favor of preferring levels to differences as instruments. As our second step of analysis, we therefore implement this 
procedure within a dynamic framework (in the following tables this corresponds to the second column for each volatility measure). Finally, as a third step, we conduct robustness tests by also including variables representing labor-market rigidities. Throughout our regressions, we take employment growth as the regressand.

We rely on Feasible Generalized Least Squares (FGLS) estimates of a model assuming the presence of cross-sectional heteroscedasticity and autocorrelation but without correction for contemporaneous correlation. ${ }^{17}$ One might argue that uncorrelatedness across our cross-sectional units (countries) is too strong an assumption because our model assigns the same parameter vector to all units in the common coefficients case, in which SUR estimates of a model with heteroscedasticity and cross-sectional correlation would be suitable. However, in view of the fact that correlations across countries might become relevant mainly in the case of symmetric shocks to the labor markets and that the probability of the latter might be small in our large sample (see, e.g., Babetski, Boone, Maurel, 2002), it is legitimate to apply a FGLS specification that assumes solely the presence of cross-section heteroscedasticity (Table 3). In order to be consistent in the sense of accounting for the possibility of symmetric shocks (i.e., contemporaneous correlation), we nevertheless apply the seemingly unrelated regression technique (SUR) in our regression analysis as well (Tables 4, 5).

The structure for presenting the estimation results is the same for Tables 3 to 5 with the exact specifications of the pooled estimation equations being described in the tables themselves. Half of the specifications include a lagged endogenous labor-market variable. All specifications contain contemporaneous real GDP growth with or without its lagged value as cyclical control, different measures of exchange rate variability and the estimates of the country-specific constants. ${ }^{18}$ The number of lags of the relevant variables were determined by the estimation itself. As in our previous studies, we limited possible lags to a number from 0 to 2 (annual data) and then tested down. Note that the number of observations in each case depends on the variables included and on their lags. The fit of each equation is checked by referring to the R-squared, the F-statistics and an AR(1) time series test for the autocorrelation of residuals. ${ }^{19}$ The latter test for AR(1) residuals is highly

\footnotetext{
${ }^{17}$ See Greene (2000, p. 592). Motivated by inspections of the country-specific residuals we include an AR error term in some of our specifications which enables us to get rid of potential autocorrelation problems in the time dimension. Following Greene (2000, p. 605), we prefer to impose the restriction of a common autocorrelation coefficient across countries in these cases.

18 The inclusion of a cyclical control variable can itself be interpreted as a first robustness test. Due to lack of space, the country-specific constants, while interesting for their own are not displayed in the tables.

19 See Wooldridge (2002), p. 176f. Serial correlation should not be present in a model which is supposed to be dynamically complete in the conditional mean. However, in cases where we implement an AR(1) term explicitly
} 
recommended by Wooldridge (2002) for dynamic panels, even including lagged endogenous variables. It regresses the dependent variable on the independent variable and the lag of residuals from the original equation. Based on this regression, a standard t-test on the significance of the coefficient of the lagged pool residuals is performed. Under the null hypothesis this coefficient is zero and, thus, there is no autocorrelation of the residuals. A nice feature of the statistics computed is that it works whether or not the regressors are strictly exogenous. Our tables for the estimation results display the empirical realization of the t-statistics jointly with the corresponding p-value (denoted as $\hat{t}$ ). Since the marginal significance level of the F-test of joint significance of all of the slope coefficients is in all cases clearly below one percent, the p-value of this test is not explicitly tabulated. However, the degrees of freedom can be easily read off the tables. ${ }^{20}$ Let us first turn to our basic regressions in Tables 3 (based on the FGLS procedure) and 4 (based on SUR estimation) for a sample consisting of all the ten EU candidate countries.

into our regression equations, the Wooldridge-test is of course not conducted for obvious reasons.

${ }^{20}$ The numerator degrees of freedom can be calculated as the number of explaining variables less one and the denominator degrees of freedom corresponds to the numbers of observations minus the number of regressors. 
Table 3: Impact of exchange rate variability on the growth of employment - FGLS estimates for 10 CEECs (fixed effects)

\begin{tabular}{|c|c|c|c|c|c|c|c|c|c|c|}
\hline Regressors & (1) & (2) & (3) & (4) & (5) & (6) & (7) & (8) & (9) & $(10)$ \\
\hline Instrument for employment growth (-1) & / & 0.10 & / & $0.14 *$ & / & / & / & $0.25 * * *$ & / & $0.18^{*}$ \\
\hline Real GDP growth rate & $0.26 * * *$ & $0.16^{* *}$ & $0.21 * * *$ & $0.15^{* *}$ & $0.24 * * *$ & $0.20 * * *$ & $0.25 * * *$ & $0.20 * * *$ & $0.27 * * *$ & $0.19 * * *$ \\
\hline \multicolumn{11}{|l|}{ Measures of exchange rate volatility: } \\
\hline $\begin{array}{l}\text { Effective volatility of } \\
\text { nominal exchange rate }\end{array}$ & $\begin{array}{c}-0.20^{* *} \\
(-2)\end{array}$ & $\begin{array}{r}-0.14 * * \\
(-2)\end{array}$ & & & $\begin{array}{c}-0.16^{*} \\
(-2)\end{array}$ & & & & & \\
\hline Effective volatility of real exchange rate & & & $\begin{array}{r}-0.11 * * * \\
(-2)\end{array}$ & $\begin{array}{r}-0.09 * * * \\
(-2)\end{array}$ & & $\begin{array}{l}-0.06^{*} \\
(-2)\end{array}$ & & & & \\
\hline $\begin{array}{l}\text { Volatility of national currency vis-à-vis } \\
\text { euro (DM) (nominal exchange rate) }\end{array}$ & & & & & & & $\begin{array}{l}-0.17 * * \\
(-2)\end{array}$ & $\begin{array}{c}-0.15^{*} \\
(-2)\end{array}$ & & \\
\hline Volatility of national currency & & & & & & & & & $-0.36^{* * *}$ & $-0.34 * * *$ \\
\hline vis-à-vis euro (DM) (real exchange rate) & & & & & & & & & $(-2)$ & $(-2)$ \\
\hline Common AR-error assumed & & & & & $\mathrm{X}$ & $\mathrm{X}$ & & & & \\
\hline \multicolumn{11}{|l|}{ Fixed effects: } \\
\hline _BG & 0.55 & 0.04 & 0.59 & 0.13 & 0.53 & -0.08 & -0.00 & 0.44 & 0.46 & 0.94 \\
\hline $\mathrm{CZ}$ & -0.73 & -0.70 & -0.22 & -0.42 & -0.79 & -0.69 & -0.83 & -0.66 & -0.57 & -0.34 \\
\hline _EE & -3.12 & -2.42 & -2.15 & -1.67 & -3.40 & -2.90 & -3.49 & -2.38 & -3.02 & -2.05 \\
\hline $\mathrm{HU}$ & -0.90 & 0.29 & -0.41 & 0.68 & -0.17 & 0.11 & -1.04 & -0.15 & -0.67 & 0.27 \\
\hline _LT & -2.01 & -1.62 & -1.09 & -0.44 & -2.37 & -1.51 & -2.15 & -1.45 & -1.61 & -0.93 \\
\hline LV & -2.18 & -0.58 & -0.40 & 0.32 & -0.95 & -0.29 & -2.39 & -1.57 & -1.66 & -0.91 \\
\hline PL & -1.40 & -0.77 & -0.90 & -0.47 & -1.27 & -1.10 & -1.47 & -1.08 & -0.91 & -0.49 \\
\hline _ $\mathrm{RO}$ & 0.48 & 0.45 & 0.79 & 0.80 & 0.09 & -0.12 & 0.25 & 0.06 & 1.19 & 0.87 \\
\hline SK & -0.55 & -1.16 & 0.13 & -0.64 & -0.74 & -0.42 & -0.66 & -0.69 & -0.42 & -0.33 \\
\hline _SL & 0.32 & 0.12 & 0.52 & 0.17 & 0.38 & 0.47 & 0.20 & 0.12 & 0.40 & 0.44 \\
\hline \multicolumn{11}{|l|}{ Weighted statistics: } \\
\hline $\mathrm{R}^{2}$ & 0.32 & 0.28 & 0.32 & 0.32 & 0.40 & 0.43 & 0.31 & 0.29 & 0.37 & 0.40 \\
\hline F-statistics & 2.82 & 1.66 & 2.91 & 2.03 & 3.11 & 3.53 & 2.64 & 2.90 & 3.49 & 3.26 \\
\hline Wooldridge $-\hat{t}$ (p-value) & $1.17(0.25)$ & $1.26(0.21)$ & $1.21(0.23)$ & $0.80(0.43)$ & / & / & $1.35(0.18)$ & $1.49(0.14)$ & $0.59(0.56)$ & $1.54(0.13)$ \\
\hline Total panel observations & 78 & 64 & 79 & 64 & 68 & 69 & 78 & 72 & 78 & 72 \\
\hline Sample & $1993-2001$ & 1994-2001 & $1993-2001$ & $1994-2001$ & $1993-2001$ & $1993-2001$ & $1993-2001$ & 1994-2001 & $1993-2001$ & 1994-2001 \\
\hline
\end{tabular}

Sample

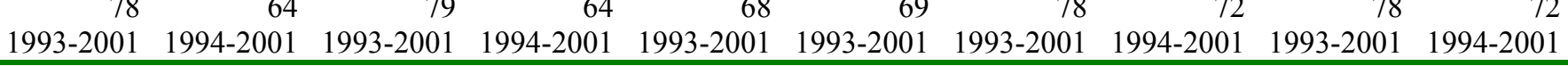

The term $\left(y_{i, t-1}-y_{i, t-2}\right)$ is instrumented by the growth of employment lagged two periods. Numbers in brackets refer to the optimal lag. 
Table 4: Impact of exchange rate variability on the growth of employment - SUR estimates for 10 CEECs (fixed effects)

\begin{tabular}{|c|c|c|c|c|c|c|c|c|c|c|}
\hline Regressors & $(1)$ & $(2)$ & (3) & $(4)$ & $(5)$ & $(6)$ & $(7)$ & $(8)$ & $(9)$ & $(10)$ \\
\hline $\begin{array}{l}\text { Instrument for the growth } \\
\text { of employment }(-1)\end{array}$ & / & 0.06 & l & $0.09 * * *$ & / & / & / & 0.05 & / & 0.04 \\
\hline Real GDP growth rate & $0.19 * * *$ & $0.11 * * *$ & $0.20 * * *$ & $0.11 * * *$ & $0.06^{* * *}$ & $0.12 * * *$ & $0.17 * * *$ & $0.10 * * *$ & $0.16^{* * *}$ & $0.09 * * *$ \\
\hline \multicolumn{11}{|l|}{ Measures of exchange rate volatility: } \\
\hline Effective volatility of nominal exchange rate & $\begin{array}{l}-0.20 * * * \\
(-2)\end{array}$ & $\begin{array}{l}-0.16 * * * \\
(-2)\end{array}$ & & & $\begin{array}{l}-0.29 * * * \\
(-2)\end{array}$ & & & & & \\
\hline Effective volatility of real exchange rate & & & $\begin{array}{l}-0.08 * * * \\
(-2)\end{array}$ & $\begin{array}{l}-0.08 * * * \\
(-2)\end{array}$ & & $\begin{array}{l}-0.13 * * * \\
(-2)\end{array}$ & & & & \\
\hline $\begin{array}{l}\text { Volatility of national currency vis-à-vis } \\
\text { euro (DM) (nominal exchange rate) }\end{array}$ & & & & & & & $\begin{array}{l}-0.16 * * * \\
(-2)\end{array}$ & $\begin{array}{l}-0.10 * * * \\
(-2)\end{array}$ & & \\
\hline $\begin{array}{l}\text { Volatility of national currency vis-à-vis } \\
\text { euro (DM) (real exchange rate) }\end{array}$ & & & & & & & & & $\begin{array}{l}-0.35 * * * \\
(-2)\end{array}$ & $\begin{array}{l}-0.08^{*} \\
(-2)\end{array}$ \\
\hline AR-error assumed & & & & & $\mathrm{X}$ & $\mathrm{X}$ & & & & \\
\hline \multicolumn{11}{|l|}{ Fixed effects: } \\
\hline _BG & 0.60 & 0.20 & 0.09 & -0.00 & 1.86 & 1.40 & -0.07 & -0.58 & 0.49 & -1.19 \\
\hline _CZ & -0.57 & 0.59 & -0.34 & -0.41 & -0.30 & -0.09 & -0.70 & -0.72 & -0.34 & -0.73 \\
\hline EE & -2.81 & -2.35 & -2.43 & -1.77 & -2.06 & -1.71 & -3.20 & -2.70 & -2.57 & -2.62 \\
\hline _HU & -0.68 & 0.45 & -0.59 & 0.73 & 1.10 & 0.77 & -0.85 & 0.29 & -0.35 & 0.30 \\
\hline LT & -1.74 & -1.47 & -0.91 & -0.49 & -1.55 & 0.40 & -1.93 & -1.72 & -1.22 & -1.79 \\
\hline${ }_{-}^{-} \mathrm{LV}$ & -1.90 & -0.46 & -1.46 & 0.27 & 0.69 & 0.76 & -2.15 & -0.72 & -1.26 & -0.73 \\
\hline _PL & -1.06 & -0.52 & -1.06 & -0.33 & -0.08 & -0.15 & -1.17 & -0.67 & -0.42 & -0.66 \\
\hline _RO & 0.54 & 0.47 & 0.48 & 0.68 & 0.48 & 0.81 & 0.25 & 0.12 & 1.25 & -0.01 \\
\hline _SK & -0.26 & -0.96 & -0.05 & -0.55 & 0.08 & 0.50 & -0.39 & -1.11 & 0.02 & -1.10 \\
\hline _SL & 0.62 & 0.36 & 0.46 & 0.35 & 1.29 & 0.99 & 0.48 & 0.27 & 0.86 & 0.31 \\
\hline \multicolumn{11}{|l|}{ Unweighted statistics: } \\
\hline $\mathrm{R}^{2}$ & 0.28 & 0.25 & 0.24 & 0.25 & 0.11 & 0.23 & 0.26 & 0.22 & 0.28 & 0.20 \\
\hline Wooldridge - $\hat{t}$ (p-value) & $1.99(0.05)$ & $1.48(0.15)$ & $3.08(0.01)$ & $1.22(0.23)$ & l & / & $2.66(0.01)$ & $0.49(0.63)$ & $1.98(0.05)$ & $0.33(0.74)$ \\
\hline Total panel observations & 78 & 64 & 79 & 64 & 68 & 69 & 78 & 64 & 78 & 64 \\
\hline Sample & 1993-2001 & 1994-2001 & 1993-2001 & 1994-2001 & 1993-2001 & $1993-2001$ & 1993-2001 & 1994-2001 & 1993-2001 & 1994-2001 \\
\hline
\end{tabular}

The term $\left(y_{i, t-1}-y_{i, t-2}\right)$ is instrumented by the growth of employment lagged two periods. Numbers in brackets refer to the optimal lag. 
It is remarkable that the estimated coefficients measuring the impact of exchange rate volatility on employment growth are mostly significant and always display the expected sign. Our empirical investigations show that exchange rate volatility enters the regression equations with at least one lag. However, in most cases the implementation of even a twoyear lag of exchange rate volatility appears superior according to the goodness-of-fit criteria. This corresponds quite nicely with the usual duration of wage contracts in the investigated countries and serves as first evidence of the absence of a reverse causation of the exchange rate volatility by employment growth. As studies for other regions suggest too, the economic impact of exchange rate volatility seems to be small but non-negligible.

As expected in view of geographical proximity, the results are in some cases slightly stronger for euro exchange rate volatility than for effective volatility. The estimated impact coefficient is larger for nominal than real volatility in the case of effective exchange rates and the other way round for the bilateral euro exchange rates. The estimated fixed effects exactly mirror the differences in employment growth, as plotted in Figure 1, with the Baltic States displaying the highest decrease in employment growth. A commonly accepted prior, the significance of contemporaneous GDP growth in determining the employment growth, is corroborated by all specifications. The available test statistics point towards correct specifications. In case of our static specifications, the Wooldridge-test indicates $\operatorname{AR}(1)$ autocorrelation of the pooled residuals. Even if we experiment with different lags of our regressors, the static specifications cannot fully capture the dynamics. Hence, we base our conclusions from Table 4 mainly on the dynamic specifications. All in all, it seems that the ten CEECs are a group too heterogeneous to be characterized by a similarly strong impact of euro exchange rate volatility. Hence, we generalized the specifications chosen above by estimating a separate coefficient of exchange rate volatility for each of the ten CEECs in order to allow for heterogeneity with respect to the impact of volatility. According to our model, this heterogeneity might stem from different degrees of labor market rigidities and/or from different levels of volatility experienced in the past. Allowing for different volatility coefficients for each CEEC, we might be able to identify those countries which drive our results. The results from the SUR procedure are reported in Table $5 .^{21}$

\footnotetext{
${ }^{21}$ Those based on FGLS lead to strikingly similar conclusions and are available on request.
} 
Table 5: Estimations based on cross-section specific coefficients of effective exchange rate volatility (SUR, fixed effects)

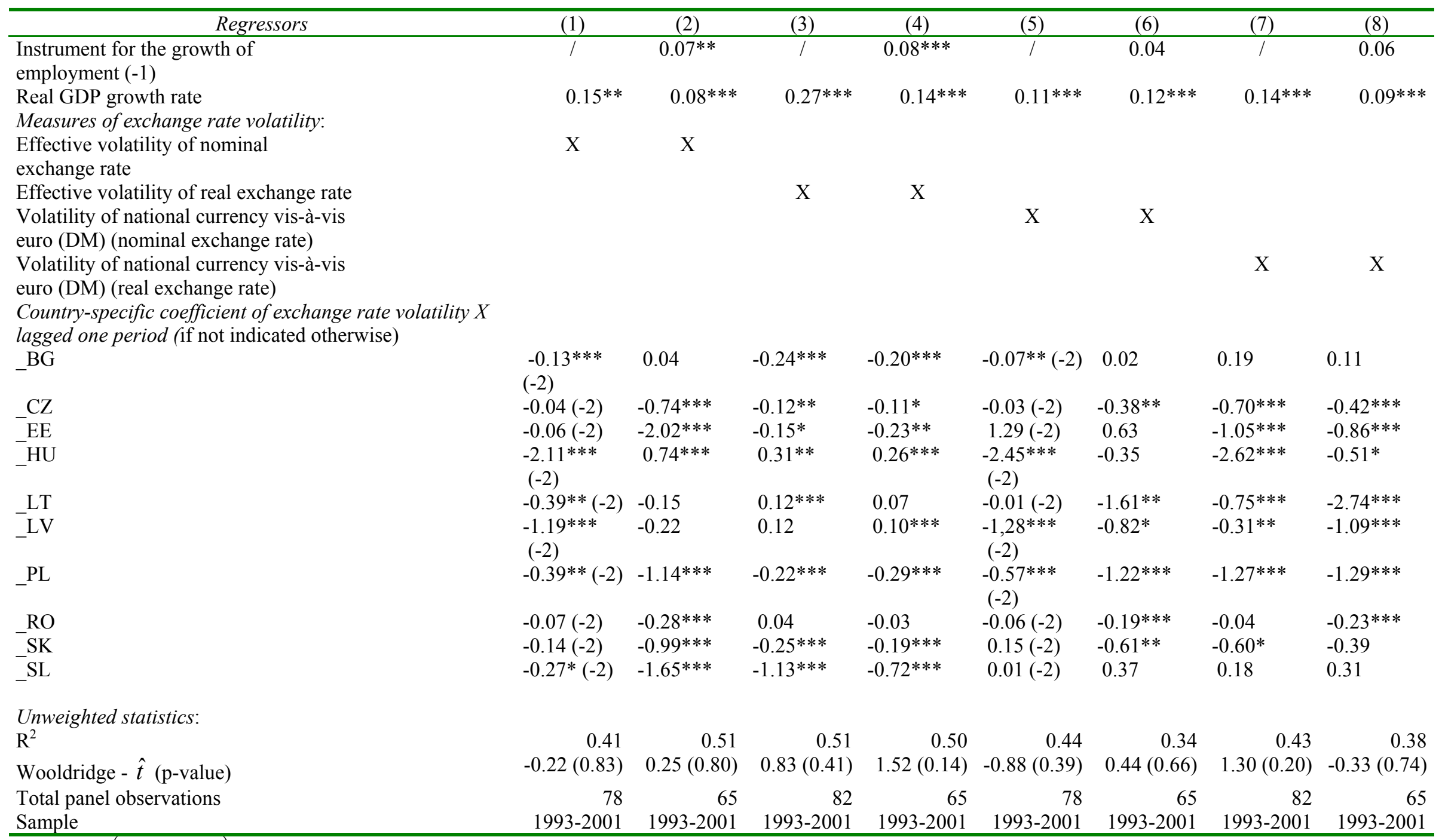

The term $\left(y_{i, t-1}-y_{i, t-2}\right)$ is instrumented by the growth of employment lagged two periods. X denotes volatility for which country-specific coefficient is estimated. Numbers in brackets refer to the optimal lag. 
This time, the best results in terms of goodness-of-fit are achieved if exchange rate volatility is included with a one-year lag. However, also if the latter is included with a two-year lag, the estimates of this variable were in most cases significant and displayed the expected negative signs. For effective volatilities, it turns out that employment growth above all in Hungary, Poland and Slovenia is significantly influenced by effective nominal exchange rate variability. If one turns to effective real exchange rate volatility, the pattern changes insofar as now the coefficient of volatility is additionally significant above all for Bulgaria, the Czech Republic, Estonia and Slovakia in both the static and the dynamic specifications. Furthermore, the remaining three countries Latvia, Lithuania and Romania are also affected by effective exchange rate variability, according to at least one specification. The results do not seem to be driven by the degree of exchange rate volatility experienced by a single CEEC, since the countries that display persistently higher effective volatility (such as Bulgaria, Romania, Latvia and Lithuania) do not display a bulk of significant coefficients of volatility. Hence, one could argue that the often stressed heterogeneity among the candidate countries becomes obvious again, now with respect to the impact of exchange rate volatility.

However, the pattern changes when the bilateral euro volatilities of the CEEC currencies are included. If one correlates these results with our considerations with regard to openness vis-àvis the eurozone, it becomes obvious that the Czech Republic, Hungary and Poland, as the economies which are most open to trade with the eurozone, are among those countries for which the results are most in line with our main hypothesis. These countries are joined by Lithuania and Latvia with four respectively three entries as well. Estonia, Romania and the Slovak Republic display two entries each. Somewhat surprisingly, Bulgaria, an often cited candidate for euroization, reveals only one entry. Finally, Slovenia does not display any evidence of negative employment impacts of exchange rate variability. With the exception of Slovenia, these results closely correspond to our expectations based on the country-specific degrees of openness described in section 2. However, according to Figure 1, Slovenia reveals one of the lowest degrees of exchange rate volatility. This is a plausible reason why Slovenia's high degrees of openness towards the eurozone and of labor market rigidities do not lead to more significant entries in Table $5 .^{22}$

\footnotetext{
${ }^{22}$ As a final step, we corroborated our analysis by extensive robustness checks. In the first step, we limit the sample to a group of rather homogenous countries with respect to labor market regulation, namely the Visegrád Economies: Czech Republic, Hungary, Poland, and the Slovak Republic. The magnitude of the estimated volatility coefficients and their significance levels increase notably. A second robustness check which includes indicators of strictness of employment protection legislation as interaction variables in the regressions also
} 
Although exchange rate variability in all of the cases does not influence employment growth contemporaneously but with a lag, employment could at least theoretically at the same time still have an impact on exchange rate variability. Unfortunately, all efforts to apply an instrument variable approach (including various measures of export demand) were impeded by our inability to find a suitable instrument for exchange rate variability. None of the instruments we tried (inter alia current accounts, short- and long-term interest rates) did work to get significant and plausible results. In other words, there is no reason to interpret exchange rate variability as endogenous.

We are skeptical in general about the possibility that exchange rate variability at our high frequency is caused by slow moving variables such as labor market rigidities or employment. Indeed, all our attempts to use an IV procedure failed because we were not able to find satisfactory instruments for exchange rate variability. Most of the fundamentals in question, with the possible exception of monetary policy, are much less variable in the short run. A further argument validating our proceedings and our results is that of Rose (1995) and Flood and Rose (1995). They emphasize that exchange rate volatility is apparently to a large extent noise (as opposed to being caused by fundamental variability). It does not make much sense to treat a noise series as endogenous. Finally, variability is a key element of an asset price, i.e. the price of currency options. If it were possible to forecast variability one could forecast option prices. Could exchange rate variability be caused by shocks? This is also rather unlikely since it has been difficult in general to document any link between exchange rate volatility and fundamentals. ${ }^{23}$ Furthermore, it is a priori unlikely that the kind of shock that requires a substantial exchange rate adjustment (a fall in export demand) occurs with a monthly frequency.

How large is the effect found in thousands of employed persons? We illustrate the answer based on the example of one of the most consistent countries in our estimations, namely Poland. Given that only one lag of exchange rate variability turned out to be important, one can directly use the t-statistic to check for the significance of the effect. With respect to the nominal variability of the zloty vis-à-vis the euro (the DM) for instance, the value of -0.57 is highly significant in the sense that the probability to find this effect if it does not exist in reality is much lower than even

performs quite well. All coefficients of the interaction variables are significant, the majority even at the 1 percent significance level. As a third and final robustness check we implement a measure for real wage growth in order to check whether the result of a significant relationship between exchange rate volatility and employment growth found in this paper is driven by a missing third variable related to labor costs. Compared with the baseline estimation, the pattern of results did not change a great deal.. Due to lack of space, the results are not presented here, but are available upon request.

${ }^{23}$ See Canzoneri, Vallés and Viñals (1996), pp. 2 ff. and 11 ff., Mélitz (1995), p. 496, and Rose (1994). 
$\alpha=0.01$ (see column 5 in Table 5). The point estimate implies that a reduction in the variability measure by one percentage point increases employment growth after one year by $0.57 \%$. Given a number of about 13,7 millions of employed Polish persons in 2001 this amounts to about 78,000 employed more. This is a quite small, but still non-negligible contribution. The effect would actually be three times as strong if the actual variability was eliminated, given the fact that in 2001 the empirical realization of the euro variability of the zloty against the euro was 3.17 percent, or at least twice as high if one eliminates the average variability (2.37 percent). With an eye on the results for the remaining countries in our sample one has to conclude that the effects for the CEECs on the whole might definitely be somewhat smaller, but still not negligible. Moreover, the results are strikingly similar to those gained for Western Europe und, thus, seem to be plausible. ${ }^{24}$

\section{Summary and outlook}

The results of this paper suggest that the high degree of exchange rate variability observed from time to time in the CEECs has tangible economic costs. Our earlier studies on intraEMS, transatlantic and Mercosur exchange rate variability have already indicated that reductions in exchange rate variability could yield substantial benefits for small open economies. It is fully possible that the same applies for most of the CEECs. It was argued that this result is due to the fact that all employment decisions have some degree of irreversibility. We investigated both effective and bilateral euro exchange rate variability since we were interested in the costs of exchange rate variability in general (effective volatilities) and in evaluating one partial benefit of euroization - the elimination of the exchange rate risk - in particular (bilateral volatilities vis-à-vis the euro). In general, our results are rather strong in that we find that exchange rate variability in many cases has a significant impact on employment growth. Moreover, the data confirm the expectation that economies with relatively closer ties with the euro zone, such as the Hungary or Poland, would show a stronger impact of euro exchange rate variability. The estimated impact coefficients were in most of the cases smaller if we pooled all of the ten CEECs. This systematic correlation between openness and the strength of the impact of exchange rate volatility on trade corresponds to the general finding of the literature, which is that for emerging markets this channel is much more important.

24 Belke and Gros (2001), for instance find for Germany that eliminating intra-European exchange rate variability of 1995, should raise the number of jobs, ceteris paribus, by 200 thousands. 
What are the implications of the results concerning the labor market impact of euro volatility for the debate on exchange rate policy in the CEECs? Given the preliminary character of our analysis, one certainly has to be cautious in terms of policy conclusions. However, our main result could be read as support for the policy conclusion that fixing exchange rates against the euro should bring significant benefits. A common argument against reducing exchange rate variability is the position that economies need some safety valve somewhere. In other words, would the suggested gains from suppressing exchange rate variability be lost, if the volatility reappeared elsewhere, for example in higher interest rate variability? We would argue that it is not possible at present to say whether the volatilities of other variables will go up or down with efforts to limit CEEC exchange rate fluctuations. But research by Rose (1999) and others indicates, for example, that official action can reduce exchange rate variability simply by holding the variability of fundamentals such as interest rates and money constant. Policy co-ordination between the central banks could thus keep the volatility of a CEEC currency vis-à-vis the Euro under control. The same is, of course, valid with respect to entering EMU.

Furthermore, it is now widely considered a stylized fact that exchange rates are disconnected from fundamentals (e.g., Obstfeld and Rogoff 2000 and the July 2002 issue of the Journal of Monetary Economics). The constant threat of speculative attacks on emerging market currencies can actually cause a co-movement of variables that does not exist for developed economies. Referring to the CEE Countries, we cannot entirely rule out the possibility that variability in the exchange rate in the 1990s has been caused by variability in monetary policy. If this were the case, the cost of exchange rate volatility reported here should be considered the cost of erratic monetary policy. We are nevertheless confident that for the Central and Eastern European EU candidate countries the general 'disconnect' between exchange rates and fundamentals also holds in the short run and is even extended to (domestic) interest rates, which for emerging markets are determined by shocks coming from international financial markets. Even if the 'disconnect' did not hold, the results gained in this paper would be of interest, since they then should fuel the debate on the relation between monetary policy rules and exchange rate variability. In this event one might come to the conclusion that, for some of the CEECs and other countries in similar situations, that monetary integration with the euro area would be the optimal monetary policy strategy. 


\section{References}

Alesina, A. and R. J. Barro (2001). "Dollarization", American Economic Review, Papers and Proceedings, 91(2), 381-385.

Arellano, M. (1989). "A Note on the Anderson-Hsiao Estimator for Panel Data", Economics Letters, 31, 337-341.

Babetski, J., L. Boone and M. Maurel (2002). "Exchange Rate Regimes and Supply Shocks Asymmetry: The Case of the Accession Countries", CEPR Discussion Paper 3408, CEPR, London.

Begg, D., B. Eichengreen, L. Halpern, J. v. Hagen, C. Wyplosz (2001). "Sustainable Regimes of Capital Movements in Accession Countries", CEPR Final Report, CEPR, London.

Belke, A. and D. Gros (2001). "Real Impacts of Intra-European Exchange Rate Variability: A Case for EMU?", Open Economies Review, 12(3), 231-264.

Belke, A. and D. Gros (2002). "Monetary Integration in the Southern Cone", North American Journal of Economics and Finance, 13(3), 323-349.

Belke, A. and D. Gros (2002a). "Designing EU-US Monetary Relations: The Impact of Exchange Rate Variability on Labor Markets on both Sides of the Atlantic", The World Economy, 25(6), 789-813.

Belke, A. and M. Hebler (2002). "The New Social Dimension of the EU: Labor Market Impacts for the Accession Countries", Constitutional Political Economy, 13(4), 313353.

Boreiko, D. (2002). "EMU and Accession Countries - Fuzzy Cluster Analysis of Membership", Paper presented at the Conference "Monetary Union: Theory, EMU Experience, and Prospects for Latin America, organized by Banco Central de Chile, Oesterreichische Nationalbank, and the University of Vienna, April 14-16, Vienna.

Buiter, W. H. and C. Grafe (2002). "Anchor, Float or Abandon Ship: Exchange Rate Regimes for the Accession Countries", Banca Nazionale del Lavoro Quarterly Review 221, June, $1-32$.

Calvo, G. A. and C. M. Reinhart (2000): "Fixing for Your Life”, NBER Working Paper 8006, NBER, Cambridge, MA.

Canzoneri, M. B., J. Vallés and J. Viñals (1996). "Do Exchange Rates Move to Address National Imbalances?”, CEPR Discussion Paper 1498, CEPR, London.

Cazes, S. (2002). "Do Labour Market Institutions Matter in Transition Economies? An Analysis of Labor Market Flexibility in the Late Nineties”, International Institute for Labour Studies Discussion Paper 140. 
de Grauwe, P. (1987). International Trade and Economic Growth in the European Monetary System, European Economic Review, 31, 389-398.

Dixit, A. (1989). Entry and Exit Decisions under Uncertainty, Journal of Political Economy, 97(3), 620-638.

Flood, R. P. and A. K. Rose (1995). Fixing Exchange Rates: A Virtual Quest for Fundamentals, in: Journal of Monetary Economics, 36(1), 3-37.

Greene, W. H. (2000). Econometric Analysis, $4^{\text {th }}$ ed., New Jersey.

Hausman, J. (1978). Specification Tests in Econometrics, Econometrica, 46(6), 1251-1271.

Hobza, A. (2002). "CEE Candidate Countries on the Way to the Eurozone, The Hague, WRR Working Document, Centre for European Policy Studies, Brussels.

Lavrac, V. (2003). "Dynamics of Inclusion of Accession Countries in the Monetary Union: Some Institutional Aspects", Paper presented at the conference "Institutions in Transition", organized by the Institute of Macroeconomic Analysis and Development (IMAD), Kranjska Gora, 12-14 June, 2003.

Levin, A. and C.-F. Lin (1992). "Unit Root Tests in Panel Data: Asymptotic and FiniteSample Properties", UCSD Department of Economics Discussion Paper 92-23, University of California, San Diego.

Mc Kinnon, R. (1999). “The East Asian Dollar Standard, Life after Death?”, Paper prepared for the World Bank Seminar "Rethinking the East Asian Miracle", July.

Meese, R. (1990). "Currency Fluctuations in the Post-Bretton Woods Era", Journal of Economic Perspectives 4(1), 117-134.

Meese, R. and K. Rogoff (1983). "Empirical Exchange Rate Models of the Seventies: Do They Fit Out of Sample?", Journal of International Economics 14(2), 3-24.

Mélitz, J. (1995). “The Current Impasse in Research on Optimum Currency Areas”, European Economic Review 39, 492-500.

NBH (2002). “Adopting the Euro in Hungary: Expected Costs, Benefits and Timing”, NBH Occasional Paper 24, National Bank of Hungary.

Nesporova, A. (2002). "Why Unemployment Remains So High in Central and Eastern Europe?”, ILO Employment Paper 43, International Labour Organisation, Geneva.

Nickell, S. (1997). "Unemployment and Labor Market Rigidities: Europe versus North America", Journal of Economic Perspectives 11(3), 55-74.

Nuti, M. (2002). "Costs and Benefits of Unilateral Euroization in Central Eastern Europe", Economics of Transition 10(2), 419-444. 
Obstfeld, M. and K. Rogoff (2000). "The Six Major Puzzles in International Macroeconomics: Is There A Common Cause?”, NBER Macroeconomics Annual, 339390, NBER, Cambridge MA.

Oesterreichische Nationalbank (2002): Focus on Transition, 1/2002, Vienna.

Oesterreichische Nationalbank (2002a): Internal Data Bank, Vienna.

Riboud, M., C. Sánchez-Páramo and C. Silva-Jáuregui (2002). "Does Eurosclerosis Matter?" Institutional Reform and Labor Market Performance in Central and Eastern European Countries in the 1990s", World Bank Social Protection Discussion Paper 0202, Washington DC.

Rose, A. K. (1994). "Exchange Rate Volatility, Monetary Policy and Capital Mobility: Empirical Evidence on the Holy Trinity", NBER Working Paper 4630, NBER, Cambridge, MA.

Rose, A. K. (1995). “After the Deluge: Do Fixed Exchange Rates Allow Inter-Temporal Volatility Trade-Offs?", CEPR Discussion Paper 1240, CEPR, London.

Rose, A. K. (1999). “One Money, One Market: Estimating the Effect of Common Currencies on Trade", NBER Working Paper 7432, NBER, Cambridge, MA.

Sapir, A. and K. Sekkat (1990). "Exchange Rate Volatility and International Trade", Chapter 8 in: P. de Grauwe, Papademos, L. (eds.), The European Monetary System in the 1990s, Longman, 182-198.

Stata Corporation (2003). STATA Reference G-M - Statistics, Graphics, Data Management, College Station, Texas.

Vienna Institute for International Economic Studies (2002). "Countries in Transition 2002", WIIW Handbook of Statistics, Vienna.

Wooldridge, J. M. (2002). Econometric Analysis of Cross-Section and Panel Data, MIT Press, Cambridge, Mass. 


\section{Annex}

Data Sources: Oesterreichische Nationalbank (2002, 2002a), Vienna Institute for International Economic Studies (2002), Estonia, Latvia, Lithuania: Eurostat and national sources.

CPI: Index of consumer prices.

GDP: Gross domestic product, real growth rate, \%.

EMP: Employment in thousand persons (all sectors), annual average.

DEMP: Employment growth in \% (logarithm)

WAGE: Average gross monthly wages, real growth rate, $\%$.

XR: specified national currency [n.c.] units) per U.S. dollar, monthly average, nominal, bilateral exchange rates vis-à-vis other countries than the U.S. calculated via cross rates.

XRR: specified national currency [n.c.] units) per U.S. dollar, monthly average, real (deflated with CPI), bilateral exchange rates vis-à-vis other countries than the U.S. calculated via cross rates.

VOLXREFF: effective volatility of nominal exchange rates (30 bilateral volatilities calculated for each CEEC, effective volatilities were generated by multiplying each of the 30 bilateral volatilities with the respective trade weight).

VOLXRREFF: effective volatility of real exchange rates (30 bilateral volatilities calculated for each CEEC, effective volatilities were generated by multiplying each of the 30 bilateral volatilities with the respective trade weight).

The following country codes apply throughout the study: BG (Bulgaria), CZ (Czech Republic), EE (Estonia), HU (Hungary), LV (Latvia), LT (Lithuania), PL (Poland), RO (Romania), SK (Slovakia), SL (Slovenia). 